\title{
PENINGKATAN SINTASAN DAN KETAHANAN LARVA UDANG WINDU (Penaeus monodon) MELALUI PENAMBAHAN BAKTERI Vibrio harveyi KE DALAM PAKAN MIKRO
}

\author{
Zafran ${ }^{*}$, Des Roza*) dan Ketut Suwirya*)
}

\begin{abstract}
ABSTRAK
Vibriosis merupakan penyakit bakterial yang dihadapi para pengelola hatcheri dalam memproduksi benih udang. Vaksinasi diyakini merupakan suatu metode yang efektif untuk mening. katkan ketahanan udang terhadap infeksi bakteri. Di Loka Penelitian Perikanan Pantai Gondol Bali, telah dilakukan penelitian untuk mengetahui pengaruh penambahan bakteri Vibrio harveyi yang sudah dimatikan ke dalam pakan mikro terhadap sintasan larva udang windu sampai stadia PL-1 dan dilanjutkan dengan uji tantang selama lima hari menggunakan bakteri $V$. harveyi hidup. Konsentrasi $V$. harveyi dalam pakan mikro adalah 0,05\% (A), 0,5\% (B), 5\% (C) dan $0 \%$ (tanpa penambahan $V$. harveyi) sebagai kontrol. Penelitian dilakukan menggunakan Rancangan Acak Lengkap dengan tiga ulangan. Penelitian terbagi atas dua percobaan. Pada percobaan pertama hanya diberi pakan mikro sedang pada percobaan ke dua selain pakan mikro juga diberikan pakan alami Chaetoreros sp. Sintasan larva pada percobaan pertama masing-masing adalah $54,33 \%$ (A), 49,00\% (B), 49.33\% (C), dan 39,00\% (kontrol), dan setelah uji tantang selama lima hari masing-masing adalah 84.8\% (A), 81.9\% (B), 78,1\% (C), dan 60.0\% (kontrol). Pada percobaan ke dua, rata-rata sintasan masing-masing perlakuan adalah $69,00 \%(\mathrm{~A}), 56,00 \%(\mathrm{~B})$, $55.00 \%$ (C), dan 40,67\% (kontrol), dan setelah uji tantang selama lima hari rata-rata sintasannya adalah 72.5\% (A), 69,17\% (B), 66,67\% (C), dan 54,17\% (kontrol). Hal ini menunjukkan bahwa penambahan bakteri $V$. harveyi yang sudah dimatikan ke dalam pakan mikro mampu meningkatkan ketahanan larva udang windu terhadap infeksi $V$. harveyi sehingga memberikan sintasan yang lebih tinggi dibandingkan dengan kontrol.
\end{abstract}

ABSTRACT: Increase of survival and resistance of giant tiger prawn larvae (Penaeus monodon) by addition of killed Vibrio harveyi into microdiet. By: Zafran, Des Roza and Ketut Suwirya.

Luminescent vibriosis is the most serious threat to giant tiger prawns (Penaeus monodon) larvae in halchery since these may cause mass mortality within a few days. Effort to combat this disease has been practiced by using a wide range of control measures, such as chemical and drug treatment. So far, the disease controls have not been quite successful. Vaccine is perceived as another alternative mean of disease control which is more economical, safe, practical and effective to enhance efficient aquaculture. An experiment on micro diets supplemented with formalin killed Vibrio harveyi was conducted at Gondol Research Station for Coastal Fisheries, Bali in June-July 1996. The purpose of the experiment was to know effects of the addition of killed $\boldsymbol{V}$. harveyi into microdiet to the survival and resistance of $P$. monodon larvae up to PL-1 and after challenged with live $\boldsymbol{V}$. harveyi for five days. Killed $\boldsymbol{V}$. harveyi were added to microdiet at a level of $0.05 \%(A)$, $0.5 \%(B)$, and $5.0 \%(C)$ dry weight based. As a control is microdiet without $V$. harveyi. The experiment was arranged in completely randomized design with three replication. Result of the first experiment (larvae fed only with test diet) showed that larvae fed with microdiet supplemented with $V$. harveyi gave higher survival than that of control, namely $54.3 \%(A), 49.0 \%(B), 49.3 \%(C)$, and $39.0 \%$ (control), respectively. After five days challenge, survival of larvae were $84.8 \%(A), 81.9 \%(B)$, $78.1 \%(C)$, and $60.0 \%$ (control), respectively. The second experiment (larvae fed with test diets and Chaetoceros sp.) showed the same phenomena. Survival of larvae up to PL-1 were 69.0\% $(A)$. $56.0 \%(B), 55.0 \%(C)$, and $40.67 \%$ (control). After challenged for five days, survival of larvar were $72.5 \%(A), 69.2 \%(B), 66.7 \%(C)$, and $54.2 \%$ (control), respectively. The results showed that the

*) Peneliti pada Loka Penelitian Perikanan Pantai Gondol, Bali 
of killed $\mathrm{V}$. harveyi into microdiet improved the survival of larval $\mathrm{P}$. monodon and preventing infection by luminescent $\mathrm{V}$. harveyi.

KEYWORDS: Penaeus monodon, survival, Vibrio harveyi.

\section{PENDAHULUAN}

Vibriosis merupakan penyakit bakterial yang umum dihadapi dalam pemeliharaan udang, baik di panti benih maupun di tambak pembesaran. Cara yang paling banyak dilakukan oleh pengelola panti benih dan petambak dalam mengatasi vibriosis adalah pemakaian antibiotik, namun tingkat keberhasilannya sangat bervariasi. Terjadinya perbedaan tingkat keberhasilan tersebut antara lain dapat disebabkan oleh pemilihan jenis dan dosis yang tidak tepat atau bakteri itu sendiri sudah mengadaptasikan diri terhadap antibiotik yang digunakan secara rutin dalam jangka waktu lama.

Vaksinasi merupakan suatu cara yang dapat dilakukan dalam penanggulangan penyakit bakterial. Pada ikan (vertebrata) penelitian tentang vaksinasi telah banyak dilakukan antara lain vaksin Aeromonas hydrophila untuk ikan lele (Supriyadi \& Rukyani, 1990), untuk ikan mas (Nugroho et al., 1990; Pasaribu et al., 1990), vaksin Vibrio anguillarum dan V. ordalii untuk ikan salmon dan "English sole" (Kamiso, 1990), serta vaksin $V$. anguillarum untuk ikan ayu (Kawano et al., 1984). Pada udang (invertebrata) efektivitas vaksin belum banyak diuji. Beberapa penelitian telah membuktikan bahwa vaksinasi mampu meningkatkan daya tahan udang terhadap infeksi Vibrio (Itami et al., 1989; 1991; 1994) terutama melalui peningkatan kemampuan fagositosis sel darah udang dan tidak menimbulkan efek negatif terhadap keragaan reproduksi udang (Pizarro \& Alfaro, 1994). Itami et al. (1991) telah menemukan bahwa penambahan $0,05 \%$ sel Vibrio sp. ke dalam pakan mikroenkapsulasi memberikan tingkat sintasan yang lebih tinggi terhadap udang windu dari stadia zoea sampai mysis. Di Indonesia, permasalahan infeksi vibrio, terutama Vibrio harveyi bercahaya tidak hanya pada stadia zoea dan mysis, tapi juga terhadap pasca-larva (Zafran et al., 1994). Sampai saat ini belum ada data apakah ada respon yang sama sebagaimana yang telah dikemukakan Itami et al. (1991) juga diberikan oleh larva udang windu sampai stadia pascalarva terhadap pakan mikro yang ditambah sel bakteri Vibrio harveyi.
Penelitian ini bertujuan untuk melihat pengaruh penambahan bakteri yang telah dimatikan ke dalam pakan mikro terhadap sintasan larva udang windu dari stadia zoea-1 sampai PL-1. Konsentrasi penambahan $V$. harveyi ke dalam pakan mikro mengacu pada Itami et al. (1991). Dari penelitian ini diharapkan ditemukan metode penanggulangan penyakit udang yang disebabkan oleh Vibrio harveyi yang lebih efektif dan berwawasan lingkungan.

\section{BAHAN DAN METODE}

\section{Udang}

Sebagai udang uji digunakan larva udang windu (Penaeus monodon) stadia zoea-1 yang diperoleh dari panti benih swasta di Situbondo, Jawa Timur. Larva berasal dari satu induk.

Penelitian ini dibagi atas dua kegiatan penelitian. Penelitian pertama larva udang windu mulai stadia zoea hanya diberi pakan mikro, sedang pada penelitian ke dua selain pakan mikro juga diberikan pakan alami Chaetoceros. Tujuan utama dari ke dua kegiatan tersebut untuk melihat perbedaan pola sintasannya.

\section{Bakteri}

Bakteri yang digunakan dalam penelitian ini adalah Vibrio harveyi yang sudah terbukti sebagai penyebab penyakit udang bercahaya. Bakteri $V$. harveyi ditumbuhkan pada media TSA selama 24 jam pada suhu $27^{\circ} \mathrm{C}$ dan selanjutnya dipanen menggunakan wadah erlenmeyer. Bakteri selanjutnya dimatikan dengan $0,5 \%$ formalin (Itami et al., 1989) dan dicuci dengan $\mathrm{NaCl} 2 \%$ sebanyak tiga kali setelah melalui proses sentrifugasi dengan kecepatan $3.100 \mathrm{rpm}$ selama 20 menit pada suhu $4^{\circ} \mathrm{C}$. Bakteri selanjutnya disimpan pada deep freezer dengan suhu $-30^{\circ}$ C sampai siap digunakan.

\section{Pakan Mikro}

Bahan utama yang digunakan sebagai pakan adalah tepung udang, tepung ikan dan tepung cumi. Komposisi lengkap dari pakan yang 
digunakan disajikan dalam Tabel 1. Ke dalam pakan secara terpisah dicampurkan sel bakteri Vibrio harveyi yang telah dimatikan dengan persentase yang berbeda, yaitu masing masing $0.05 \%$ (A), $0.5 \%$ (B), $5 \%(C)$, dan $0 \%$ (D) sebagai kontrol. Wadah pemeliharaan udang yang digunakan dalam penelitian ini adalah stoples kaca volume $2.5 \mathrm{I}$, yang diisi $2 \mathrm{~L}$ air laut dan 100 ekor larva udang windu stadia zoea-1. Wadah penelitian ditempatkan dalam penangas air yang dilengkapi pompa sirkulasi air sehingga suhu merata dan stabil pada $29^{\prime \prime} \pm 1^{\prime \prime} \mathrm{C}$. Pakan dibuat dalam dua ukuran yang berbeda yakni yang lewat saringan $88 \mu$ dan $175 \mu$. Pakan ukuran $\leq 88 \mu$ diberikan pada larva stadia zoea sampai mysis awal. sedang pakan ukuran $\leq 175 \mu$ diberikan pada larva stadia mysis sampai pascalarva. Pakan diberikan lima kali sehari masing-masing pada pukul 6.00, 11.00, 14.00, 18.00, dan 21.00 WITA Penelitian dirancang dalam bentuk Rancangan Acak Lengkap (RAL) dengan tiga ulangan. Pengamatan dilakukan terhadap sintasan larva pada akhir penelitian (stadia PI,-1) dan setelah uji tantang selama lima hari. Perkembangan stadia larva diamati secara mikroskopis. Stadia PL-1 biasanya dicapai lima hari setelah penetasan telur. Data sintasan ditransformasikan ke dalam arc. Sin sebelum dianalisis ragam.

\section{Uji tantang}

Larva stadia pasca-larva 1 dari masing-masing kelompok perlakuan di atas dimasukkan masingmasing 25 ekor ke dalam gelas kaca volume $2,5 \mathrm{~L}$ yang diisi $2 \mathrm{~L}$ air laut yang sudah disterilisasi menggunakan sinar ultra violet. Masing-masing perlakuan diulang tiga kali. Ke dalam tiap gelas kaca tersebut selanjutnya diinfeksikan bakteri Vibrio harveyi hidup berumur 24 jam pada kepadatan $1,2 \times 10^{6} \mathrm{cfu} / \mathrm{mL}$. Pengamatan dilakukan terhadap sintasan setiap 24 jam setelah infeksi selama lima hari. Pada malam hari juga dilakukan pengamatan untuk melihat apakah kematian larva benar disebabkan oleh infeksi Vibrio harveyi bercahaya. Larva yang terinfeksi $V$. harveyi bercahaya mudah diamati pada malam hari (kondisi gelap) sebab larva tersebut akan terlihat bercahaya.

Tabel 1. Komposisi pakan.

Table 1. Composition of basal diet.

\begin{tabular}{lc}
\hline \multicolumn{1}{c}{ Bahan (Ingredient) } & $\begin{array}{c}\text { Persentase(\%) } \\
\text { Percentage (\%) }\end{array}$ \\
\hline Kasein (Casein) & 10 \\
Tepung ikan (Fish meal) & 20 \\
Tepung udang (Shrimp meal) & 15 \\
Tepung cumi (Squid meal) & 10 \\
Sukrose (Sucrose) & 10 \\
Dekstrin (Dextrin) & 8 \\
Pati( $\alpha$-starch) & 4 \\
Kolesterol (Cholesterol) & 1 \\
Minyak ikan pollack (Pollack liver oil) & 4 \\
Minyak kedelai (Soybean oil) & 2 \\
Lesitin (Lecithin) & 2 \\
Campuran vitamin (Vitamin mix) & 2 \\
Campuran mineral (Mineral mix) & 5 \\
Karaginan (k-Carrageenan) & 7 \\
\hline
\end{tabular}




\section{HASIL DAN PEMBAHASAN}

\section{Percobaan 1. Larva hanya diberi pakan mikro}

Sintasan larva sampai stadia PL-1 disajikan dalam Tabel 2. Pada Tabel 2 terlihat bahwa penambahan bakteri Vibrio harveyi yang sudah dimatikan ke dalam pakan mikro memberikan sintasan yang lebih tinggi dan secara statistik berbeda nyata $(\mathrm{P}<0,05)$ dengan kontrol yang tanpa penambahan bakteri $V$. harveyi. Tetapi antara penambahan 0,05\%: 0,5\% dan 5\% ternyata tidak berbeda nyata $(\mathrm{P}>0,05)$.

Penambahan sel mati bakteri Vibrio harveyi ternyata mampu meningkatkan ketahanan tubuh udang terhadap infeksi bakteri. Itami et al. (1991) dalam penelitiannya terhadap larva $P$. monodon stadia zoea sampai mysis juga telah membuktikan bahwa penambahan bakteri Vibrio sp. yang dimatikan ke dalam pakan mikro mampu me- ningkatkan sintasan larva di mana penambahan $0,05 \%$ bakteri memberikan hasil yang terbaik.

Hasil uji tantang selama lima hari terhadap larva stadia PL-1 dari masing-masing perlakuan menunjukkan hasil vang senada di mana larva yang diberi pakan mikro yang ditambah sel mati bakteri $V$. harveyi memberikan tingkat sintasan yang lebih tinggi $(\mathrm{P}<0,05)$ dibandingkan kontrol.

\section{Percobaan 2. Larva diberi pakan mikro dan Chatoceros sp.}

Pada percobaan 2 di mana larva udang windu diberi pakan mikro dan Chaetoceros sp. pola sintasannya ternyata sama dengan pola sintasan dalam percobaan 1 , sintasan larva yang lebih baik ternyata juga diberikan oleh perlakuan pakan mikro yang ditambah sel mati Vibrio harveyi. Hasil lengkap sintasan larva udang windu untuk masing-masing perlakuan dapat dilihat pada Tabel 3

Tabel 2. Rata-rata sintasan (\%) larva udang windu yang diberi pakan mikro yang ditambah sel mati bakteri Vibrio harveyi dengan persentase berbeda sebelum dan sesudah uji tantang.

Table 2. Average survival rate (\%) of giant tiger prawn larvae fed with microdiet containing different concentrations of dead cells of Vibrio harveyi before and after challenge test.

\begin{tabular}{|c|c|c|c|c|c|c|}
\hline \multirow{2}{*}{$\begin{array}{c}\text { Perlakuan }(\% \\
\text { sel mati bakteri) } \\
\text { Treatment } \\
(\% \text { killed } \\
\text { bacteria) } \\
\end{array}$} & \multirow{2}{*}{$\begin{array}{c}\text { Sintasan sampai } \\
\text { PL-1 } \\
\text { Survival up to } \\
\text { PL-1 } \\
(\%)\end{array}$} & \multicolumn{5}{|c|}{$\begin{array}{l}\text { Sintasan setelah } 5 \text { hari uji tantang }(\%) \\
\text { Survival following } 5 \text {-day challenge }(\%)\end{array}$} \\
\hline & & $\begin{array}{l}24 \\
\text { jam (hours) }\end{array}$ & $\begin{array}{c}48 \\
\text { jam (hours) }\end{array}$ & $\begin{array}{c}72 \\
\text { jam (hours) }\end{array}$ & $\begin{array}{c}96 \\
\text { jam (hours) }\end{array}$ & $\begin{array}{l}120 \\
\text { jam (hours) }\end{array}$ \\
\hline 0.05 & $54.3 \pm 0.6^{\mathrm{a}}$ & $98.1 \pm 1.7^{\prime \prime}$ & $97.1 \pm 2.8$ & $95.2 \pm 4.4^{\circ}$ & $92.4 \pm 4.3$ & $84.8 \pm 4.4^{b}$ \\
\hline 0.50 & $49.0 \pm 8.5^{\circ}$ & $95.2 \pm 3.3^{\prime \prime}$ & $92.4 \pm 7.2^{\mathrm{bc}}$ & $88.6 \pm 2.8^{\mathrm{kH}}$ & $84.8 \pm 4.4^{1 x}$ & $81.9 \pm 1.7^{b}$ \\
\hline 5.00 & $49.3+2.9^{\prime \prime}$ & $92.4 \pm 7.2:$ & $86.7 \pm 1.7^{\mathrm{ab}}$ & $82.9 \pm 2.8^{\text {ah }}$ & $78.1 \pm 3.3^{\mathrm{ah}}$ & $78.1 \pm 3.3^{b}$ \\
\hline Kontrol (Control) & $39.0+2.0^{11}$ & $81.9 \pm 6.0^{\circ}$ & $73.3 \pm 15.8^{: 1}$ & $67.6 \pm 14.1^{\mathrm{a}}$ & $64.8 \pm 16.5^{\mathrm{a}}$ & $60.0 \pm 14.8^{\prime \prime}$ \\
\hline
\end{tabular}

Nilai dalam kolom dikuti huruf supershrip yang sama tidak berbeda nyata pada P:(0,05

Values in columns followed by the same superseript letter are not significantly different at P:O.05 
Tabel 3. Sintasan (\%) larva udang windu yang diberi pakan mikro yang ditambah sel mati bakteri $V$. harveyi dengan persentase berbeda dan Chaetoceros setelah diuji tantang dengan Vibrio harveyi pada konsentrasi $1,2 \times 10^{6} \mathrm{cfu} / \mathrm{mL}$.

Table 3. Survival rate the larvae of $\mathrm{P}$. monodon fed with microdiet containing different concentrations of dead cells of Vibrio harveyi and Chaetocheros after challenged to V. harveyi at concentration of $1.2 \times 10^{6} \mathrm{cfu} / \mathrm{mL}$

\begin{tabular}{|c|c|c|c|c|c|c|}
\hline \multirow{2}{*}{$\begin{array}{l}\text { Perlakuan (\% sel } \\
\text { mati bakteri) } \\
\text { Treatment }(\% \\
\text { killed Bacteria) }\end{array}$} & \multirow{2}{*}{$\begin{array}{c}\text { Sintasan } \\
\text { sampai PL-1 } \\
\text { Survival up to } \\
\text { PL-1 }(\%)\end{array}$} & \multicolumn{5}{|c|}{$\begin{array}{l}\text { Sintasan setelah } 5 \text { hari uji tantang }(\%) \\
\text { Survival following } 5 \text {-day challenge }(\%)\end{array}$} \\
\hline & & $\begin{array}{c}24 \\
\text { jam (hours) }\end{array}$ & $\begin{array}{c}48 \\
\text { jam (hours) }\end{array}$ & $\begin{array}{c}72 \\
\text { jam (hours) }\end{array}$ & $\begin{array}{c}96 \\
\text { jam (hours) } \\
\end{array}$ & $\begin{array}{c}120 \\
\text { jam (hours) }\end{array}$ \\
\hline 0.05 & $69.0 \pm 1.0^{\mathrm{a}}$ & $78.3 \pm 6.5^{\prime \prime}$ & $77.5 \pm 5.0^{\mathrm{h}}$ & $75.8 \pm 6.3^{\prime \prime}$ & $74.2 \pm 6.3^{1 "}$ & $72.5 \pm 4.3^{\mathrm{b}}$ \\
\hline 0.50 & $56.0 \pm 2.6^{11}$ & $76.7 \pm 5.2^{\prime \prime}$ & $75.0 \pm 2.5^{11}$ & $73.3 \pm 3.8^{\prime \prime}$ & $71.7 \pm 1.4^{\prime \prime}$ & $69.2 \pm 2.9^{b}$ \\
\hline 5.00 & $55.0 \pm 3.6^{\prime \prime}$ & $73.3 \pm 7.6^{\circ}$ & $72.5 \pm 6.6^{\mathrm{b}}$ & $71.7 \pm 6.3^{\prime \prime}$ & $69.2 \pm 6.3^{\prime \prime}$ & $66.7 \pm 1.4^{h}$ \\
\hline Kontrol (Control) & $40.7 \pm 2.1$ & $65.0 \pm 6.6^{\circ}$ & $61.7 \pm 2.9^{\prime \prime}$ & $60.0 \pm 2.5^{\mathrm{a}}$ & $56.7 \pm 3.8^{\mathrm{a}}$ & $54.2 \pm 3.8^{\prime \prime}$ \\
\hline
\end{tabular}

Nilai dalam kolom diikuti huruf superskrip yang sama tidak berbeda nyata pada P:0,05

Values in columns followed by the same superscript letter are not significantly different at P:0.05

Pada Tabel 3 terlihat bahwa penambahan $0,05 \%$ sel mati bakteri Vibrio harveyi ke dalam pakan mikro memberikan sintasan terbaik $(\mathrm{P}<0,05)$ dibanding perlakuan lain. Walaupun penelitian ini belum dapat menjelaskan bagaimana mekanisme kerja sel mati $V$. harveyi dalam pakan dalam meningkatkan sintasan dan ketahanan larva terhadap infeksi vibrio, diduga bakteri memainkan peran penting sebagai sumber nutrea dalam pakan yang dapat mendukung proses metamorfosis larva udang dalam pertumbuhannya dan sebagai suatu substansi untuk mengaktifkan mekanisme pertahanan larva udang dari infeksi bakteri patogen yang terdapat dalam lingkungan air pemeliharaan (Itami et al., 1991). Pemberian 0,05\% sel mati bakteri $V$. harveyi merupakan jumlah optimum yang dapat diberikan kepada larva udang windu. Pemberian bakteri dengan persentase di atas $0,05 \%$ diduga mempunyai efek negatif terhadap larva udang windu, yaitu meracuni larva itu sendiri. Boonyaratpalin et al., (1995) menyatakan bahwa penambahan peptidoglycan (senyawa yang terdapat pada dinding luar bakteri), di atas kadar optimum dapat merugikan bagi udang itu sendiri. Sebelumnya, Sung et al. (1994) menyatakan bahwa imunostimulan itu dapat diibaratkan sebagai pedang bermata ganda, dapat menguntungkan dan dapat pula merugikan, tergantung dosis yang digunakan.

Pada uji tantang, setelah 24 jam belum terlihat adanya perbedaan daya tahan larva udang dari masing-masing perlakuan terhadap infeksi Vibrio harveyi $(\mathrm{P}>0,05)$. Dua hari setelah uji tantang, perbedaan sintasan yang lebih mencolok antara kelompok yang diberi pakan mikro dan kontrol tampak jelas $(\mathrm{P}<0,05)$. Setelah lima hari (120 jam), sintasan masih sama dengan 48 jam, tetapi terdapat perbedaan yang nyata antara perlakuan dan kontrol. Ini menunjukkan bahwa penambahan sel mati bakteri dalam pakan mikro efektif meningkatkan daya ketahanan larva terhadap serangan $V$. harveyi. Paterson dan Keith (1992) dari penelitiannya terhadap krustase lain, yakni lobster Homarus americanus menemukan bahwa perangsangan dengan bakteri gram negatif atau gram positif mampu mening. katkan kemampuan pertahanan tubuh lobster terhadap bakteri patogen, yakni dengan peningkatan jumlah serta kemampuan fagositosis sel. Peningkatan fagositosis sel juga dapat dipacu melalui penggunaan imunostimulan (Itami et al.. 1994; Boonyaratpalin et al., 1995). Sung et al., (1994) telah membuktikan bahwa ketahanan larva udang windu terhadap infeksi Vibrio juga dapat ditingkatkan melalui perendaman dalam suspensi glucan, yaitu salah satu imunostimulan.

\section{KESIMPULAN}

Berdasarkan hasil penelitian yang diperoleh maka dapat ditarik kesimpulan sebagai berikut:

1. Rata-rata sintasan larva udang windu yang hanya diberi pakan mikro pada perlakuan 
penambahan $0.05 \%, 05 \%, 5 \%$, dan $0 \%$ sel mati V.harveyi sampai stadia PL-1 masing-masing adalah $54,33 \%, 49,00 \%, 49,33 \%$, dan $39,00 \%$, sedangkan setelah uji tantang selama 120 jam rata-rata sintasannya berturut-turut adalah $84,8 \%, 81,9 \%, 78,1 \%$, dan $60,0 \%$.

2. Pada percobaan pemberian pakan mikro dan Chaetoceros sp., rata-rata sintasan pada penambahan $0.05 \%, 0.5 \%, 5 \%$, dan $0 \%$ sel mati $V$. harveyi sampai stadia PL-1 masing-masing adalah $69,00 \%, 56,00 \%, 55,00 \%$, dan $40,67 \%$, sedangkan setelah uji tantang selama 120 jam masing-masing adalah $72,5 \%, 69,17 \%, 66,67 \%$, dan $54.17 \%$.

3. Penambahan bakteri Vibrio harveyi yang telah dimatikan sebanyak $0,05 \%$ ke dalam pakan mikro mampu meningkatkan sintasan dan ketahanan larva udang windu terhadap infeksi Vibrio harveyi.

\section{DAFTAR PUS'TAKA}

Boonyaratpalin. S., M. Boonyaratpalin, K. Supamataya, and Y. Toride. 1995. Effects of peptidoglycan $(\mathrm{PG})$ on growth, survival, immune response. and tolerance to stress in black tiger shrimp, Penaeus monodon. In Shariff, M., J.R. Arthur, and R.P. Subasinghe (Eds.), Disease in Asian Aquaculture II. Fish Health Section, Asian Fisheries Society, Manila, Philippines. 469-477.

Itami, T., Y. Takahashi, and Y. Nakamura. 1989. Efficacy of vaccination against vibriosis in cultured Kuruma prawn Penaeus japonicus. J. of Aqua. Anim. Health 1(3):238-242.

Itami, T., Y. Takahashi. K. Yoneoka, and Y. Yan. 1991. Survival of larvae giant tiger prawns Penaeus monodon after addition of killed vibrio cells to microencapsulated diet. J. of Aqua. Anim. Health $3(2): 151-152$

Itami, T., Y. Takahashi, E. Tsuchihira, H. Igusa, and M. Kondo. 1994. Enhancement of disease resistance of Kuruma prawn Penaeus japonicus and increase in phagocytic activity of prawn hemocytes after oral administration of $\beta-1,3$ (Schizophyllan). In Chou of al. (Eds.). Proceedings of The Third Asian Fisheries
Forum. The Asian Fisheries Society, Manila. Philippines. 375-378

Kamiso, H.N. 1990. Vaksinasi untuk mencegah vibriosis pada ikan. Dalam Rukyani et al. (Eds.), Prosiding Seminar Nasional II Penyakit Ikan dan Udang. Bogor 16-18 Januari 1990. Balitkanwar, Bogor. 53-63

Kawano, K., T. Aoki, and T. Kitao. 1984. Efficacy of direct immersion vaccination of Ayu Plecoglossus altivelis with Vibrio anguillarum bacterin. Fish Pathology, 16(4):211-214

Nugroho, E., S.L. Anka, dan D. Bastiawan. 1990. Peningkatan daya tahan ikan terhadap infeksi Aeromonas hydrophilla dengan cara vaksinasi. Dalam Rukyani et al. (Eds.), Prosiding Seminar Nasional II Penyakit Ikan dan Udang, Bogor 16-18 Januari 1990. Balitkanwar, Bogor. 83-86

Pasaribu, F.H., N. Dalimunthe, dan M. Poeloengan. 1990. Pengobatan dan pencegahan penyakit ikan dan bercak merah. Dalam Rukyani et al. (Eds.), Prosiding Seminar Nasional II Penyakit Ikan dan Udang. Bogor 16-18 Januari 1990. Balitkanwar, Bogor. 143-152.

Paterson, W.D., and I.R. Keith. 1992. Disease and defense mechanisms of the American Lobster. Homarus americanus. In Shariff. M., R.P. Subasinghe, and J.R. Arthur (Eds.), Disease in Asian Aquaculture I. Fish Health Section, Asian Fisheries Society, Manila, Philippines. 81-87.

Pizarro, F. and J. Alfaro. 1994. Reproductive performance of Penaeus stylirostris females injected with heat-killed Vibrio alginolyticus. J. of World Aqua. Soc. 25(4):576-577.

Supriyadi, H. dan A. Rukyani. 1990. Imunoprofilaksis dengan cara vaksinasi pada usaha budidaya ikan. Dalam Rukyani et al. (Eds.), Prosiding Seminar Nasional II Penyakit Ikan dan Udang, Bogor 16-18 Januari 1990. Balitkanwar, Bogor. 64-70

Sung, H.H., G.H. Kou, and Y.L. Song. 1994. Vibriosis resistance induced by glucan treatment in tiger shrimp (Penaeus monodon). Fish Pathology, 29(1):11-17.

Zafran, D.R. Boer, K. Sugama, K. Hatai, and S. Wada 1994. Histological study of luminescents Vibrio harveyi infection in hatchery reared larvae of Penaeus monodon. In Proceedings of Third Asian Fisheries Forum, Singapore. 294-297. 